\title{
Preferensi dan Kesediaan Konsumen Membayar Salak Pondoh Organik
}

\author{
Endro Isnugroho ${ }^{1}$,Susilo B. Winarno ${ }^{2}$ \\ STIE Pariwisata API Yogyakarta \\ E-mail : stieapi@gmail.com
}

\begin{abstract}
Salak Pondoh Sleman has received Geographical Indication protection. Geographical Indication is part of Intellectual Property Rights (IPR) which is a universal concept showing the origin of the quality and characteristics of an item. This product is characterized as an organic with international standard management in the Sleman Regency. This study aims to predict the willingness of consumers to pay (willingness to pay or WTP) salak pondoh products that already have previlege available in the Sleman domestic market, with the intention of the results can be used to provide useful insights in outlining the promotion strategy of organic zalaka products, especially in the salak pondoh labeling program. In order to build a description and choice inference for purchasing salak pondoh, a structured questionnaire instrument was presented to 220 respondents with a purposive sampling method. The characteristics and descriptions of purchasing preferences of zalacca were measured by Chi Square analysis and to determine the effect of product brand image variables (brand image) and brand awareness on the willingness of consumers to pay (WTP) regression analysis was used. This brand variable as a proxy for premium salak pondoh products has received geographical indication protection. The results showed that differences in education levels and differences in the magnitude of consumer spending determine the preference for purchasing premium type of salak pondoh, which is zalacca with a relatively high price. Brand image and product awareness have a positive effect on the willingness of consumers to pay for premium products. The obstacle in this study is that at the time of research the availability of premium zalacca products based on both types of seeds and organic management was minimal in the market, resulting in relatively high price differences between organic or superior types and ordinary salak pondoh.
\end{abstract}

Keywords: geographical indications of salak pondoh, willingness to pay, brand equity, organic

Abstrak - Salak Pondoh Sleman telah mendapatkan perlindungan Indikasi Geografis. Indikasi Geografis merupakan bagian dari Hak Kekayaan Intelektual (HKI) yang merupakan konsep universal menunjukkan asal kualitas dan karakteristik suatu barang. Produk ini dicirikan sebagai organik dengan pengelolaan berstandar internasional di wilayah Kabupaten Sleman. Penelitian ini bertujuan untuk memprediksi kesediaan konsumen membayar (willingness to pay or WTP) produk salak pondoh yang telah memiliki previlege yang tersedia di pasar domestik Sleman, dengan maksud hasilnya dapat dipergunakan untuk memberikan wawasan bermanfaat dalam menguraikan strategi promosi produk salak organik, terutama dalam program pelabelan salak pondoh. Guna membangun suatu deskripsi dan inferensi pilihan pembelian salak pondoh digunakan instrumen kuesioner terstruktur disajikan kepada 220 orang responden dengan metode purposive sampling. Karakteristik dan deskripsi dari preferensi pembelian salak pondok diukur dengan analsis Chi Square dan untuk mengetahui pengaruh variabel imej merek produk (brand image) dan kesadaran merek (brand awareness) terhadap kesediaan konsumen membayar (WTP) digunakan analisis regresi. Variabel merek ini sebagai proksi pada produk premium salak pondoh telah mendapatkan perlindungan indikasi geografis. Hasil penelitian menunjukkan bahwa perbedaan tingkat pendidikan dan perbedaan besarnya pengeluaran konsumen menentukan preferensi dalam pembelian salak pondoh jenis premium yaitu salak dengan harga yang relatif tinggi. Imej merek (brand image) dan kesadaran produk (brand awareness) berpengaruh positif terhadap kesediaan konsumen membayar produk premium. Kendala dalam penelitian ini adalah pada saat penelitian ketersediaan produk salak premium baik berdasarkan jenis bibit maupun pengelolaan organik sangat minim di pasaran, sehingga terjadi perbedaan harga relatif tinggi antara salak organik atau jenis unggul dan salak pondoh biasa.

Kata kunci: hak indikasi geografis salak pondoh, kesediaan membayar, ekuitas merek, organic

\subsection{Latar Belakang}

Salak Pondoh telah menjadi trade mark Kabupaten Sleman sebagai produk pertanian yang memiliki kekhasan dan kualitas tinggi. Keistimewaan salak pondoh adalah rasa manis dan enak sejak buah masih muda, apalagi setelah masak (masir). Keistimewaan ini menjadikan trade mark Salak Pondoh sebagai alternatif oleh-oleh dari Jogja. Saat ini, salak Pondoh Sleman telah mendapatkan perlindungan Indikasi Geografis. Indikasi Geografis merupakan bagian dari Hak Kekayaan Intelektual (HKI) yang merupakan konsep universal menunjukkan asal kualitas 
dan karakteristik suatu barang. Berbeda dengan merek, merek tidak menunjukkan kualitas, reputasi dan karakteristik produk secara langsung, sedangkan Indikasi Geografis mampu secara langsung menunjukkan asal dan karakteristik produknya, berujud barang dan dimiliki secara komunalistik (Winarno, 2014). Jangka waktu perlindungan ini berlangsung selama ciri dan/atau kualitas yang menjadi dasar diberikan perlindungan tersebut masih ada, sehingga apabila ciri dan kualitas barang dapat dipelihara dan dipertahankan dalam waktu tertentu dapat menciptakan citra dan reputasi yang memungkinkan barang tersebut memiliki nilai ekonomi tinggi. Contoh produk lain yang mempunyai perlindungan Indikasi Geografis seperti Cilembu dari daerah Cilembu Jawa Barat, Kopi Toraja dari daerah Tana Toraja Sulawesi Selatan, Kopi Kintamani, Carica dari Wonosobo, dan lain-lain (http://ebook.dgip.go.id/indikasi-geografis/?book=kopiarabika-toraja)

Capaian ini tidak terlepas dari peran serta Pemerintah Daerah dan komunitas produsen salak melalui kelembagaan pengelola salak pondoh seperti asosiasi dan paguyuban. Bukti keberhasilan ini terlihat bahwa Kabupaten Sleman merupakan sentra produksi salah pondoh terbesar di Daerah Istimewa Yogyakarta. Oleh karena itu, salak jenis ini mempunyai nilai ekonomi yang tinggi dan prospek yang cerah dalam menghimpun Pendapatan Asli Daerah, bahkan sebagai penghasil devisa negara. Permasalannya adalah seberapa besar potensi dari previlege dapat dipasarkan secara optimal. Produk ini mempunyai keunggulan dalam standart pengelolaan produksi menyangkut bibit, pemeliharaan, dan anti pestisida. Analsisis kesediaan konsumen membayar (willingness to pay=WTP) sangat berguna dalam strategi penetapan harga yang sesuai dengan lingkungan dan dapat terhindar dari resiko karena mengabaikan potensi yang dimiliki suatu produk.

Penelitian willingness to pay (WTP) biasa digunakan untuk mengukur kelayakan dalam formulasi strategi harga khususnya untuk produk baru atau yang memberikan potensi manfaat bagi penggunanya. Penelitian banyak dilakukan pada produk yang menyangkut lingkungan seperti jenis green product, anti pestisida atau organik dan produk pengendali lingkungan dimana pada produk tersebut terkandung biaya lingkungan yang harus ditanggung konsumen. Penelitian ini mengurai potensi produk salak pondoh yang telah dilindungi hak indikasi geografisnya dalam sudut pandang pemasarannya. Sebagai produk musiman salak pondoh mengalami fluktuasi hasil produksi yang berimbas pada harga produk. Sementara produk buah-buahan telah masuk pasar secara luas dengan menggunakan label organik dan mampu menunjukkan eksistensinya sepanjang waktu. Penelitian ini mencoba untuk menganalisis faktor-faktor prognostik niat konsumen untuk membayar premi harga hijau salak pondoh Sleman yang telah mendapatkan perlindungan indikasi geografis. Produk ramah lingkungan memerlukan daftar potensi manfaat bagi lingkungan karena terbuat dari sumber daya ramah lingkungan, Tulisan ini bertujuan untuk menganalisis pengaruh merek (brand image) dan kesadaran merek (brand awareness) terhadap kesediaan membayar (willingness to pay).

\subsection{Kajian Pustaka}

Karateristik produk organik pertanian dicirikan dengan tidak adanya unsur pestisida dalam proses produksinya baik secara langsung maupun tidak langsung. Hal ini dikhawatirkan beresiko tidak hanya pada manusia sebagai konsumen, namun lingkungan tempat produksinya. Selain itu, dalam arti altruistik, kekhawatiran signifikan tentang kerusakan pestisida terhadap satwa liar, pekerja pertanian, dan lingkungan, yang mendukung untuk mengurangi penggunaan pestisida bagi produk (Weaver et al, 1992). Pengelolaan terhadap produk organik sebagai produk berkualitas unggul membutuhkan penanganan khusus dan metode tertentu. Itulah sebabnya output dan penjualan produk organik relatif kecil dibandingkan produk konvensional (Govindasamy dan Italia, 1999).

Kesediaan konsumen untuk membayar dikenal dengan willingness to pay (WTP), yaitu kesediaan konsumen mendapatkan suatu produk dengan pengorbanan maksimal. Menurut Breidert et al (2006) WTP sangat berguna dalam strategi penetapan harga yang sesuai dengan lingkungan dan dapat terhindar dari resiko karena mengabaikan potensi yang dimiliki suatu produk. Studi praktis yang berbeda telah menunjukkan bahwa variasi kecil dalam penetapan harga dan perilaku konsumen yang sesuai dapat memiliki efek penting pada pendapatan dan laba.

Menurut Rodriguez et al. (2008) informasi tentang atribut kualitas dari produk makanan ke fihak konsumen, produsen, pemerintah dan peneliti umumnya tidak lengkap (imperfect), karena tidak setiap produk diuji. Informasi yang aktual dari sebuah kualitas merupakan pengetahuan seseorang yang dibawanya dan digunakan suatu saat dalam pengambilan keputusan. Seorang 
konsumen selalu melakukan identifikasi pada hampir setiap produk yang diadopsinya. Modal pengetahuan ini biasa disebut brand awareness.

Dalam perspektif tradisional kesejahteraan ekonomi adalah nilai barang atau jasa yang digunakannya atau manfaat yang diperolehnya. Kehidupan saat ini tidak hanya dicukupi dengan kebutuhan hari ini saja, namun juga disiapkan kebutuhan yang akan datang, sehingga munculah persepsi yang dibangun dalam fikirannya (Catalano et al. 2016). Persepsi tersebut menempel pada produk bahkan mungkin sangat hiperbal. Keadaan seperti ini bahkan kadang sangat liar disebut brand image.

Dalam teori pemasaran sebuah merek adalah makna di balik nama, logo, simbol dan slogan perusahaan. Merek diciptakan dalam bentuk yang unik dan mudah diingat konsumen, sehingga konsumen mengingatnya untuk jangka waktu yang relatif pajang. Kemampuan konsumen memahami merek menunjukkan bahwa produk tersebut sangat dikenal baik dalam target pasar. Menurut Kokemuller (2016), langkah pertama dalam membangun tujuan promosi adalah menciptakan pemahaman merek pada target pasarnya. Sebelum membuat kesan yang baik atau memotivasi pelanggan untuk membeli, maka konsumen harus memahami merek dan makna pesan pesan penting terkait dengan produk-produknya yang disampaikan melalui berbagai media.

Tingkat tertinggi kesadaran merek adalah top of mind awareness, artinya ketika pelanggan membeli suatu produk dalam kategori yang dibutuhkan, maka yang terpikir pertama kali adalah produk yang kita dibanding dengan yang lain. Top of mind awareness dibangun melalui paparan yang berulang-ulang dan proses penyampaian/persediaan produk yang konsisten dari waktu ke waktu. Hal ini adalah keunggulan yang bernilai tinggi dalam suatu pasar dimana tingkat persaingan produknya sangat ketat.

Ekuitas merek menurut Kotler dan Amstrong (1999) adalah nilai suatu merek berdasarkan sejauh mana merek tersebut mempunyai loyalitas merek, kesadaran nama merek, anggapan kualitas, asosiasi merek yang tinggi dan aset lain seperti paten, merek dagang, distribusi dan indikasi geografis. Keller (1993) membedakan ekuaitas merek menjadi dua kategori, yaitu kesadaran merek (brand awarness) dan imej merek (brand image). Kesadaran merek merupakan kemampuan konsumen dalam melakukan identifikasi terhadap merek dalam berbagai kondisi. Imej merek merupakan persepsi konsumen terhadap asosiasi suatu merek yang tersimpan dalam ingatannya. Konsumen mencari asosiasi merek yang kuat dengan manfaat (benefit) yaitu dari segi fungsional, pengalaman dan simbol-simbol. Keyakinan dan kepercayaan konsumen terhadap suatu merek produk menciptakan pelanggan yang loyal.

Kesediaan menerima (willingness to accept $=$ WTA) dan kesediaan membayar (willingness to pay= WTP) adalah suatu konsep evaluasi keekonomian produk berkaitan dengan nilai tambah (added value) suatu produk atau jasa (Martin et. al, 2010). WTA berkaitan dengan produk dan bentuk layanannya, sementara WTP berkaitan dengan aspek moneter. Seperti contoh tanaman organik yang bebas dari residu kimia mungkin dapat diterima di pasar, namun tidak dapat diserap konsumen mengingat kualitas produk berkaitas erat dengan harga, sehingga WTA mendapat tanggapan positif namun WTP tidak signifikan.

Menurut Horowitz dan McConnell (2000) pada produk yang mempunyai substitusi atau produk pengganti relatif tinggi, maka rasio WTA terhadap WTP relatif rendah sebaliknya ketika produk pengganti rendah rasio WTANTP relatif tinggi. Demikian salak pondok relatif banyak varietasnya dan konsumen mempunyai alternatif banyak dalam menentukan jenis salak yang dipilih atau dibelinya. Namun standarisasi dari preferensi konsumen perlu diperjelas dengan suatu tanda atau pelabelan. Oleh karena itu penelitian ini mengajukan hipotesis:

1. Imej merek (brand image) berpengaruh positif terhadap kesediaan membeli (willingness to pay) pada harga premium.

2. Kesadaran merek (brand awareness) berpengaruh positif terhadap kesediaan membeli (willingness to pay) pada harga premium.

\subsection{Metode Penelitian}

Penelitian difokuskan pada wilayah Kabupaten Sleman, khususnya daerah Turi dan Pakem sebagai kelompok tani yang mendapatkan perlindungan indikasi geografis (HKI). Obyek penelitian ini adalah kesediaan membayar (willingness to pay) produk salak pondoh pada harga premium, sedangkan subjek penelitian adalah pembeli atau calon pembeli salak pondoh.

Penelitian ini dilakukan dalam dua model, yaitu eksploratori dan inferensi. Dalam eksploratori permasalahan yang ada dihasilkan dari pengembangan beberapa variabel yang berhubungan dan mendukung 
penelitian ini, tanpa didasari oleh suatu model baku. Adapun model inferensi digunakan analisis regresi linier berganda. Pada umumnya pada penelitian willingness to pay dengan pengambilan data direct survey digunakan conjoint analisys dan atau contingent valuation namun juga dimungkinkan model perseptual (Hahsler \& Reuterer, 2015). Dengan mempertimbangkan karakteristik produk yang bersifat musiman dan harga berfluktuatif, maka penelitian diarahkan pada persepsi kesediaan membayar seperti dalam penelitian Biswas (2016) A studi of consumers' willingness to pay for green products. Adapun sampel diambil sebanyak 220 responden, toleransi kesalahan sebesar $7 \%$.

Kuesioner dibagi dalam 3 (tiga) bagian, bagian pertama A memuat tentang data identitas dan pola pembelian buah salak (6 pertanyaan), bagian kedua $B$ memuat pemahaman tentang salak pondoh (6 pertanyaan) dan bagian ketiga $C$ pernyataan tentang imej merek (brand image), kesadaran merek (brand awareness) dan kesediaan membayar (willingness to pay). Skala pengukuran dengan skala likert data ordinal 4 skala, yaitu Sangat Setuju (SS) $=4$; Setuju (S) =3; Tidak Setuju (TS) =2; Sangat Tidak Setuju $(S)=1$. Dalam hal ini tidak memberikan ruang jawaban Netral.

\subsection{Variabel, Definisi Konsep dan Operasional}

Variabel bebas adalah variabel yang menjadi sebab timbulnya atau berubahnya variabel dependen (Sugiono 2003: 3). Variabel independen terdiri atas: (1) Imej merek (brand image) dan, 2. Kesadaran merek (brand awareness). Sedangkan variabel terikat (dependent variable) merupakan variabel yang dipengaruhi atau yang terjadi akibat adanya variabel bebas.

Brand Image (Imej merek) merupakan persepsi konsumen terhadap asosiasi suatu merek yang tersimpan dalam ingatannya. Konsumen mencari asosiasi merek yang kuat dengan manfaat (benefit) yaitu dari segi fungsional, pengalaman dan simbol-simbol. Keyakinan dan kepercayaan konsumen terhadap suatu merek produk menciptakan pelanggan yang loyal. Persepsi green product atau organik dinyatakan dalam bentuk kuesioner bahwa salak pondoh bersahabat dengan lingkungan, keyakinan sebagai obat bagi kesehatan tubuh, suatu prestise saat mengkonsumsinya dan pilihan lain dari yang ada sebelumnya dan kualitas yang lebih baik.

Brand Awareness (kesadaran merek) merupakan kemampuan konsumen dalam melakukan identifikasi terhadap merek dalam berbagai kondisi. Pertanyaan yang diajukan seperti produk organik bebas dari racun atau bahan kimia berbahaya, produk yang lebih tahan lama, standart kualitas terukur dan pelabelan merupakan garansi fihak ketiga pada penggunaya (user).

Willingness to pay (kesediaan membayar) menunjukkan kesediaan individual/pelanggan mengeluarkan secara maksimum cost untuk memperoleh layanan atau konsumsi produk tertentu (Biswas, 2016). Konsep evaluasi keekonomian produk berkaitan dengan nilai tambah (added value) suatu produk atau jasa (Martin et. al, 2010).Dalam penelitian ini secara asosiasi disampaikan pertanyaan kepada responden tentang usaha memperoleh produk organik atau produk varietas unggul, manfaat keekonomian dari manfaat produk, kesediaan membayar dengan harga premium untuk suatu alasan dan membayar pada harga premium sebagai kesadaran pada lingkungan.

Tabel III.1 Variabel, Definisi Konsep dan Operasional

\begin{tabular}{|c|c|c|}
\hline Variabel & $\begin{array}{l}\text { Definisi } \\
\text { konsep }\end{array}$ & $\begin{array}{c}\text { Definisi } \\
\text { Operasional }\end{array}$ \\
\hline $\begin{array}{l}\text { Variabel } \\
\text { bebas }\left(\mathrm{X}_{1}\right) \\
\text { Imej Merek } \\
\text { (brand } \\
\text { image) }\end{array}$ & $\begin{array}{l}\text { Imej merek } \\
\text { merupakan } \\
\text { persepsi } \\
\text { konsumen } \\
\text { terhadap } \\
\text { asosiasi suatu } \\
\text { merek yang } \\
\text { tersimpan } \\
\text { dalam } \\
\text { ingatannya. } \\
\text { Konsumen } \\
\text { akan mencari } \\
\text { asosiasi } \\
\text { merek yang } \\
\text { kuat dengan } \\
\text { manfaat } \\
\text { (benefit) yaitu } \\
\text { dari segi } \\
\text { fungsional, } \\
\text { pengalaman } \\
\text { dan simbol- } \\
\text { simbol. (Keller } \\
\text { 1993) }\end{array}$ & $\begin{array}{l}\text { - } \text { persepsi } \\
\text { peduli } \\
\text { terhadap } \\
\text { lingkungan } \\
\text { - } \text { persepsi } \\
\text { positif sebagai } \\
\text { alternatif } \\
\text { pengobatan } \\
\text { - persepsi } \\
\text { tentang } \\
\text { prestise } \\
\text { - persepsi } \\
\text { pilihan yang } \\
\text { lebih baik }\end{array}$ \\
\hline $\begin{array}{l}\text { Variabel } \\
\text { bebas }\left(\mathrm{X}_{2}\right) \\
\text { Kesadaran } \\
\text { Merek } \\
\text { (brand } \\
\text { awareness) }\end{array}$ & $\begin{array}{l}\text { Kesadaran } \\
\text { merek } \\
\text { merupakan } \\
\text { kemampuan } \\
\text { konsumen } \\
\text { dalam } \\
\text { melakukan } \\
\text { identifikasi } \\
\text { terhadap } \\
\text { merek dalam } \\
\text { berbagai } \\
\text { kondisi (Keller, } \\
\text { 1993) }\end{array}$ & 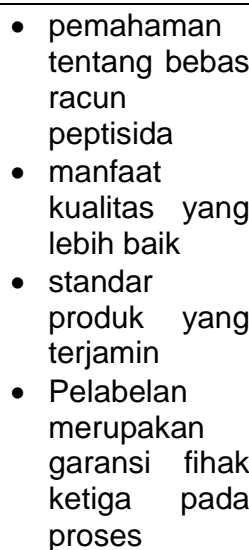 \\
\hline
\end{tabular}




\begin{tabular}{|c|c|c|}
\hline & & produksi \\
\hline $\begin{array}{l}\text { Variabel } \\
\text { terikat (Y) } \\
\text { Kesediaan } \\
\text { membayar } \\
\text { (willingness } \\
\text { to pay) }\end{array}$ & $\begin{array}{l}\text { Wllingness to } \\
\text { pay (WTP) } \\
\text { adalah suatu } \\
\text { konsep } \\
\text { evaluasi } \\
\text { keekonomian } \\
\text { produk } \\
\text { berkaitan } \\
\text { dengan nilai } \\
\text { tambah } \\
\text { (added value) } \\
\text { suatu produk } \\
\text { atau jasa } \\
\text { (Martin et. al, } \\
\text { 2010). }\end{array}$ & $\begin{array}{l}\text { - } \text { upaya kuat } \\
\text { membeli } \\
\text { produk } \\
\text { organik } \\
\text { - Trade-off } \\
\text { manfaat lebih } \\
\text { besar } \\
\text { daripada } \\
\text { pengorbanan } \\
\text { biaya } \\
\text { Kesediaan } \\
\text { membayar } \\
\text { harga } \\
\text { premium } \\
\text { sebagai } \\
\text { souvenir } \\
\text { Rela } \\
\text { membayar } \\
\text { lebih tinggi } \\
\text { untuk } \\
\text { kebutuhan } \\
\text { lingkungan }\end{array}$ \\
\hline
\end{tabular}

\subsection{Uji Validitas dan Reliabilitas}

Uji validitas adalah suatu ukuran yang menunjukkan tingkat-tingkat kevalidan atau kesahihan suatu instrumen. Diukur menggunakan program SPSS analisis skala menunjukkan hasil yang sahih.

Tabel. III.2 Ringkasan Uji Validitas Konsumsi

\begin{tabular}{|c|c|c|c|}
\hline \multicolumn{4}{|c|}{ Salak Pondoh Organik } \\
\hline Variabel & $\begin{array}{c}\text { r Hitung } \\
\text { (Corrected } \\
\text { Item Total } \\
\text { Correlation) }\end{array}$ & r Tabel & Ket. \\
\hline $\begin{array}{l}\text { Imej merek (Brand } \\
\text { Image) } \\
\text { - Persepsi } \\
\text { organik } \\
\text { berkaitan } \\
\text { dengan peduli } \\
\text { lingkungan } \\
\text { - Konsumsi } \\
\text { organik sebagai } \\
\text { alternatif } \\
\text { pengobatan } \\
\text { Organis } \\
\text { sebagai suatu } \\
\text { prestise } \\
\text { Lebih baik dari } \\
\text { produk } \\
\text { konvensional }\end{array}$ & $\begin{array}{l}0,614 \\
0,702 \\
0,738 \\
0,585\end{array}$ & 0.361 & Valid \\
\hline $\begin{array}{l}\text { Kesadaran merek } \\
\text { (Brand awareness) } \\
\text { - Organik bebas } \\
\text { dari } \\
\text { racun/peptisida } \\
\text { - Produk organik } \\
\text { lebih tahan } \\
\text { lama } \\
\text { - Produk organik } \\
\text { memiliki standar } \\
\text { - Pelabelan } \\
\text { merupakan }\end{array}$ & $\begin{array}{l}0,639 \\
0,794 \\
0,703 \\
0,674\end{array}$ & 0.361 & Valid \\
\hline
\end{tabular}

\begin{tabular}{|c|c|c|c|}
\hline $\begin{array}{l}\text { jaminan } \\
\text { fihak ketiga }\end{array}$ & & & \\
\hline $\begin{array}{l}\text { Kesediaan } \\
\text { konsumen membeli } \\
\text { pada harga } \\
\text { premium } \\
\text { - Berusaha } \\
\text { membeli } \\
\text { meskipun } \\
\text { mahal } \\
\text { - Secara manfaat } \\
\text { produk organik } \\
\text { relatif murah } \\
\text { - Untuk oleh-oleh } \\
\text { rela membayar } \\
\text { lebih } \\
\text { Kesediaan } \\
\text { membayar } \\
\text { biaya } \\
\text { lingkungan }\end{array}$ & $\begin{array}{l}0,748 \\
0,687 \\
0,635 \\
0,671\end{array}$ & 0.361 & Valid \\
\hline
\end{tabular}

Sumber: Data Primer 2018

Tabel III.2 di atas menunjukkan bahwa semua butir-butir dari ketiga variabel menunjukkan hasil yang valid dimana $r$ hitung yang merupakan corrected item total correlation lebih besar daripada $r$ tabel untuk 30 df 2 sebesar 0,361. Demikian pula uji reliabilitas menunjukkan hasil yang valid dengan rule of thumb 0,6 .

\subsection{Implementasi Sistem, Hasil Dan Pembahasan}

\subsubsection{Analisis Deskripsi}

Dalam keputusan pembelian konsumen dihadapkan pada preferensi, yaitu suatu sikap suka atau tidak suka terhadap objek barang yang bergerak secara bertingkat. Preferensi sendiri memiliki sifat dasar kelengkapan, transivitas dan kontinuitas, sehingga individu biasa menentukan keputusannya berdasarkan fokus tertentu (point of interest). Penelitian ini menguji point of interest dalam pembelian salak dengan menyebutkan rangking pemilihan salak dari (1) bentuk yang besar, (2) warna kulit yang cerah, (3) rasa yang difavoritkan, (4) jenis varietas unggul/organik, dan (5) faktor harga. Jawaban dari 220 responden dapat ditampilkan pada tabel di bawah:

Tabel IV.1 Perangkingan Fokus Pertimbangan Pembelian Salak Pondoh

\begin{tabular}{|c|c|c|c|c|c|}
\hline $\begin{array}{c}\text { Pemilih } \\
\text { Rangking }\end{array}$ & Besar & $\begin{array}{c}\text { Warna } \\
\text { Kulit }\end{array}$ & Rasa & $\begin{array}{c}\text { Jenis/ } \\
\text { Varietas } \\
\text { organi })\end{array}$ & Harga \\
\hline 1 & 28 & 15 & 56 & 79 & 40 \\
\hline 2 & 34 & 12 & 89 & 33 & 59 \\
\hline 3 & 72 & 27 & 42 & 19 & 60 \\
\hline 4 & 57 & 63 & 19 & 39 & 41 \\
\hline 5 & 29 & 103 & 14 & 50 & 20 \\
\hline $\begin{array}{c}\text { Bobot } \\
\text { tertimbang }\end{array}$ & 635 & 433 & 814 & 712 & 718 \\
\hline
\end{tabular}

Sumber: Data Primer 2018 
Tabel IV.4 Perangkingan pertimbangan pembelian salak pondoh menunjukkan sebaran yang unik, bahwa varietas unggul atau tipe organik menjadi pilihan ranking pertama terbanyak yang menjadi pertimbangan dalam pembelian salak pondoh, yaitu sebanyak 79 responden, namun juga menempati pilihan akhir sebanyak 50 responden. Pada saat penelitian mid 2018 harga premium salak pondok di tingkat pengepul hingga 3 kali harga salah pondoh biasa. Hal ini memberi indikasi bahwa keputusan pada produk organik terbagi dua secara jelas.

Apabila ranking tersebut dilakukan pembobotan, ranking 1 dengan bobot 5 , ranking 2 dengan bobot 4 , ranking 3 dengan bobot 3 , ranking 4 dengan bobot 2 dan ranking bawah dengan bobot 1, maka bobot tertimbang tertinggi justru pada pilihan rasa dengan total nilai 814 , disusul kemudian faktor harga dengan bobot 718 baru kemudian jenis varietas unggul 712 , kemudian bentuk yang besar 635 dan warna 433. Bagaimanapun juga faktor rasa menjadi pertimbangan yang paling populer, meskipun sesungguhnya semua atribut pilihan tersebut saling berkaitan dengan harga. Sebagai contoh untuk menjadikan salak yang besar, maka dalam pemeliharaannya juga harus mengorbankah salak lainnya untuk memberikan tempat salak lainnya berkembang. Untuk menjadi bibit varietas unggul dibutuhkan pengorbanan pemeliharaan yang lebih dan menambah cost maupun tenaga.

Pilihan utama konsumen pada rasa adalah hal yang wajar sesuai fungsinya, dengan total bobot tertimbang yang paling tinggi dan sebaran preferensi wajar (skewness negatif). Bobot tertimbang terendah pada pilihan warna kulit, mungkin hanya orang yang terbiasa berkecimpung dengan dunia salak dapat mengetahui keadaan salak hanya dengan melihat warna kulitnya. Faktor harga memperlihatkan urutan kedua sedikit lebih tinggi dibanding faktor organik atau jenis salak. Faktor ini dapat dideskripsikan lebih lanjut pada karakteristik responden berdasarkan pengeluaran belanjanya. Adapun faktor besaran salak menjadi pertimbangan ke 4 setelah pilihan jenis.

Untuk memahami gambaran siapa yang yang cenderung membeli salak pondoh varietas unggul atau organik dilakukan dengan menggunakan tabulasi silang yaitu dengan melihat peta pilihan antara pemeringkatan preferensi organik dengan beberapa karakteristik reponden. Dengan menggunakan Chi-Square, hasilnya adalah:
1. Ada perbedaan antara besaran pengeluaran dengan preferensi pilihan organik secara signifikan $(\alpha=1 \%)$ dimana mereka yang berpengeluaran belanja lebih besar, lebih memilih salak organik. Hasil ini sesuai dengan penelitian Govindasamy \& Italia (1999).

2. Ada perbedaan antara tingginya tingkat pendidikan dengan preferensi pilihan organik secara signifikan $(\alpha=5 \%$ ) dimana mereka yang berpendidikan tinggi, lebih memilih salak organik. Hasil ini berbeda dengan penelitian Govindasamy \& Italia (1999). Penelitian Govindasamy tidak menujukkan perbedaan tinggi pendidikan dengan pilihan produk organik.

3. Karakteristik responden lainnya seperti gender, umur, pekerjaan tidak menunjukkan perbedaan secara signifikan.

\subsection{Analisis Inferensi}

Untuk menguji adanya pengaruh imej merek (brand image) dan kesadaran merek terhadap kesediaan membayar (willingness to pay) salah satu alat analisis adalah alat analisis regresi berganda. Dari data responden kesioner kelompok $\mathrm{C}$ diperoleh hasil persamaan regresi seperti di bawah ini (lihat lampiran 4).

$\begin{array}{llrr}Y & =-1,465+0,323 \mathrm{X}_{1}+0,708 \mathrm{X}_{2} \\ \text { s. e. } & =(1,135) & (0,115) & (0,130) \\ t & =(-1,290) & (2,811) & (5,451) \\ \text { sig. } & =(0,198) & (0,05) & (0,000) \\ \mathrm{R}^{2} & =0,386 & & \end{array}$

Keterangan:

$\mathrm{Y} \quad=$ kesediaan membayar (willingness to pay)

$\mathrm{X}_{1} \quad=$ imej merek (brand image)

$\mathrm{X}_{2}=$ kesadaran merek (brand awareness)

Dari persamaan di atas bahwa variabel independen yaitu imej merek (brand image) dan kesadaran merek (brand awareness) secara bersama-sama berpengaruh positif dan signifikan $(\alpha=1 \%)$ terhadap kesediaan membayar (willingness to pay). Kesadaran merek lebih menunjukkan pengaruh yang robust. Artinya pembelian produk organik lebih didasarkan pada pengetahuan secara detil tentang fungsi dan manfaat produk.

\subsection{Simpulan dan Rekomendasi}

Hasil eksplorasi menggunaan analasis deskriptif dengan tabulasi silang bahwa:

\subsubsection{Simpulan}

1. Preferensi terhadap produk dengan varietas unggul dan/atau organik ditunjukkan dengan pilihan responden terbanyak pada jenis salak super, yaitu varietas unggul atau organik. Responden 
yang memilih peringkat satu untuk atribut ini sebanyak 79 orang $(35,91 \%)$ kemudian diikuti oleh atribut rasa yang mendapat dukungan 56 responden $(25,45)$ disusul harga 40 responden $(18,18 \%)$, selanjutnya atribu bentuk dan warna masing-masing $28(12,73 \%)$ dan 15 (6,82\%). Hal ini membuktikan kesadaran responden terhadap kualitas yang memberikan persepsi bahwa salak organik baik bagi kesehatan tubuh dan kelangsungan lingkungan. Sebaliknya, responden yang mengabaikan pilihan pada jenis salak organik ini juga tidak sedikit, karena jumlah responden paling banyak hingga 50 orang. Mungkin kelompok ini yang menilai bahwa masih ada alternatif lain yang dapat menggantikan salak pondoh organik dengan harga yang lebih murah.

2. Terdapat perbedaan yang signifikan berdasarkan karakteristik responden dari besarnya pengeluaran belanja terhadap pemeringkatan produk organik, dimana semakin besar pengeluaran belanja pilihan produk varietas organik lebih tinggi. Pengeluaran belanja yang besar merupakan proksi dari penghasilan yang tinggi. Hal ini menunjukkan bahwa kendala harga pada produk organik tidak berpengaruh pada mereka yang berpenghasilan tinggi, atau kebutuhan jaminan dalam kualitas yang dibelinya. Hasil penelitian ini sama dengan penelitian Griffith and Neshiem (2016).

3. Terdapat perbedaan yang signifikan berdasarkan karakteristik Pendidikan terhadap pemeringkatan produk salak organik, dimana semakin tinggi pendidikan pilihan pada produk organik lebih tinggi. Sangat dimungkinkan bahwa pendidikan yang tinggi memberikan kesadaran emosional dan kepedulian pada kesehatan dan lingkungan, sehingga mereka yang berpendidikan relatif tinggi bersedia membelanjakan uangnya untuk lingkungan. Penelitian ini berbeda dengan Govindasamy \& Italy (1999).

4. Secara rata-rata berdasarkan bobot tertimbang, faktor rasa menempati peringkat ter atas. Manfaat pada produk makanan adalah rasa, sehingga sudah barang tentu faktor rasa menjadi pilihan utama. Namun pengalaman konsumen menunjukkan bahwa faktor rasa sudah termasuk dalam jaminan produk organik sehingga manfaat lain menjadi pilihannya. Hasil penelitian ini sama dengan hasil penelitian Cerda et al. (2012)
5. Berdasarkan hasil analisis regresi bahwa:

a. Secara parsial imej merek (brand image) berpengaruh positif dan signifikan $(\alpha=5 \%)$ terhadap kesediaan membayar (willingness to pay). Hipotesis 1. terbukti.

b. Kesadaran merek (brand awareness) berpengaruh positif dan signifikan $(\alpha=$ $1 \%$ ) terhadap kesediaan membayar (willingness to pay). Hipotesis 2 terbukti

\subsubsection{Rekomendasi}

1. Antusiasme terhadap produk varietas unggul dan/atau organik relatif tinggi, sebaiknya pemegang kepentingan mendorong produsen dalam hal ini petani agar bersedia untuk beralih menghasilkan salak organik, baik dengan atau tanpa insentif untuk mengisi pasar dalam negeri memenuhi permintaan yang relatif tinggi. Ketersediaan salak pondoh berlabel organik relatif sedikit di pasar, sementara hasil penelitian menunjukkan bahwa salah pondoh telah menjadi produk preferensi tinggi, mungkin dapat dikembangkan ke arah cindera mata atau oleh-oleh.

2. Tingkat pendidikan dan tingkat penghasilan yang direpresentasikan dengan tingkat pengeluaran merupakan partisipan yang tepat sebagai sasaran promosi dan pengembangan produk. Sangat dimungkinkan bahwa sasaran yang tepat pemasaran produk organik kepada mereka yang tngkat ekonominya tinggi atau mereka yang berpendidikan tinggi.

3. Brand image dan brand awareness merupakan faktor yang mempengaruhi Willingness to pay, sehingga fihak pemasar salak pondoh varietas unggul dan/atau organik dapat memfokuskan brand knowledge salak pondoh. Sangat baik membangun imajinasi masyarakat dengan kampanye lingkungan dan kesehatan masyarakat dengan mengkonsumsi produk organik yang bebas bahan kimia buatan. Apalagi saat ini momentum untuk memulai makan makanan sehat sedang menjadi trend.

\section{Daftar Pustaka}

[1] Biswas, A. (2016). A Study of Consumers' Willingness to Pay for Green Products. Journal of Advanced Management Science, 4(3), 211-215. https://doi.org/10.12720/joams.4.3.211-215 
[2] Breidert, C. (2005). ePub WU Institutional Repository Estimation of Willingness-toPay Theory, Measurement, and, (April).

[3] Breidert, C., Hahsler, M., \& Reutterer, T. (2015). A Review of Methods for Measuring Willingness-to-Pay, 1(4).

[4] Brien, O., \& Viramontes, J. L. (2009). Willingness to Pay: A Valid and Reliable Measure of Health, 289-297.

[5] Catalano, G., Florio, M., \& Giffoni, F. (2016). Willingness to pay for basic research: a contingent valuation experiment on the large hadron collider. ArXiv Preprint ArXiv:1603.03580, 1-28.

[6] Cerda, A. A., García, L. Y., Ortega-Farías, S., \& Ubilla, Á. M. (2012). Consumer preferences and willingness to pay for organic apples. Ciencia e Investigación Agraria, 39(1), 47-59. https://doi.org/10.4067/S071816202012000100004

[7] Chapman, J., Dean, M., Ortoleva, P., Snowberg, E., \& Camerer, C. (2017). Willingness to Pay and Willingness to Accept are Probably Less Correlated Than You Think. NBER Working Paper Series, 66. https://doi.org/10.3386/w23954

[8] Cookson, R. (2003). Willingness to pay methods in health care: A sceptical view. Health Economics, 12(11), 891-894. https://doi.org/10.1002/hec.847

[9] Govindasamy, R., \& Italia, J. (1999). Predicting willingness-to-pay a premium for organically grown fresh produce. Journal of Extension, 30, 44-53. Retrieved from

http://ageconsearch.umn.edu/bitstream/27 385/1/30020044.pdf

[10] Griffith, R., \& Nesheim, L. (2008). Consumers willingness to pay for organic products. Fiscal Studies, 1-59. https://doi.org/10.1920/wp.cem.2008.1808

[11] Horowitz, J. K and McConnell, K. E. (2000), Willingness to Accept, Willingness to Pay and the Income Effect, Paper, Department Agriculture and Resource Economics University of Maryland. College Park MD 20742-5535

[12]Keller, K. L. (1993), Conceptualing, Measuring and Managing Customer-Based Brand Equity, Jurnal of Marketing, Vol.57: 1-19

[13] Kokemuller, (2016), http://smallbusiness.chron.com/importance -brand-awareness-45853.html (12 Des 2018)

[14] Levinson, E. (2010). Green clothes: A survey of people's willingness to pay for environmentally clothes. Differences, 51. Retrieved from http://www.divaportal.org/smash/get/diva2:350380/FULLT EXT01.pdf

[15] Liebe, U., Preisendörfer, P., \& Meyerhoff, J. (2011). To pay or not to pay: Competing theories to explain individuals' willingness to pay for public environmental goods. Environment and Behavior, 43(1), 106130. https://doi.org/10.1177/001391650934622 9

[16] McFadden, D. (1998). Measuring willingness to pay for transportation improvements. Theoretical Foundations of Travel Choice Modeling, 339-364.

[17] PP Nomor 51 tahun 2007 tentang Indikasi Geografis

[18] Rodríguez, E., Lacaze, V., \& Lupín, B. (2008). Contingent Valuation of Consumers , Willingness-to-Pay for Organic Food in Argentina. 12th Congress of the European Association of Agricultural Economists-EAAE 2008, 1-10. Retrieved from http://ageconsearch.umn.edu/bitstream/43 947/2/151.pdf

[19] Sugiyono, (2006), Statistika untuk Penelitian, Bandung: Alfabeta

[20] Undang-undang Nomor 15 Tahun 2001 tentang Merek

[21] Weaver, R. D., Evans, D. J., \& Luloff, A. E. (1992). Pesticide use in tomato production: Consumer concerns and willingness-to-pay. Agribusiness, 8(2), 131-142.

[22] Wertenbroch, K., \& Skiera, B. (2002). Measuring Consumers' Willingness to Pay at the Point of Purchase. Journal of Marketing Research, 39(2), 228-241. https://doi.org/10.1509/jmkr.39.2.228.1908 6

[23] Winarno, B. S. (2014). Budaya Komunalistik Hak Kekayaan Intelektual terhadap Hak Indikasi Geografis Salak Pondoh di Kabupaten Sleman. Penelitian Dosen Pemula (tidak diterbitkan)

[24] http://www.dgip.go.id 